A second policy change is that we will no longer consider for publication letters that are not typed with double spacing between the lines. We have stated for the past two years in our instructions to authors that letters should be prepared in this way, but most of the letters we receive are not. Indeed, many of them are very poorly presented-in a way that would not be acceptable if they were papers. Many authors seem not to realise that their letters have to be subedited and then read by a printer who sets them in type.

While embarked on this moan, I want to point out two other policies that we have for our correspondence columns and to which many of our readers seem oblivious. Firstly, unlike many other scientific publications our correspondence columns are reserved primarily for letters that relate to articles that we have published. We try to avoid original publications (what we call "out of the blue")-these we consider as papers or short reports and so referee in the normal way. This rule does not apply to letters on political and policy matters.

Secondly, we are unenthusiastic about publishing letters more than six weeks after the article to which they refer. If a writer wants to take part in the argument about an article then he must be quick. One corollary to this policy is that our overseas readers who want to have letters published will need to make sure that they have access to an airmail edition of the journal.

We are not inflexible bureaucrats, and all of these rules may be broken. But their aim is to make our correspondence columns more readable and immediate and to give as many people as possible a chance to have their say. We hope, therefore, that our readers will cooperate.

RICHARD SMITH Assistant editor

\section{Cytomegalovirus infections in renal transplant recipients}

After renal transplantation up to $60 \%$ of seronegative recipients and nearly $90 \%$ of seropositive recipients may show evidence of cytomegalovirus infection. ${ }^{1}$ While many such patients remain clinically asymptomatic, the infection is associated with considerable morbidity and mortality. ${ }^{1-3}$

Impairment of renal function developing after transplantation may be due to rejection or cytomegalovirus infection, and the distinction is vital clinically, since the former requires an increase in immunosuppressive drugs whereas in the latter the dose has to be decreased. ${ }^{4}$ Studies from Boston have shown that about half the patients with cytomegalovirus viraemia and renal impairment have diffuse glomerular lesions with only minimal interstitial damage. This finding helps to differentiate patients with cytomegalovirus infection from those having rejection episodes. ${ }^{45}$ Changes in the ratio of $\mathrm{T}$ lymphocyte subset populations may also help since the ratio of OKT4 (helper/inducer) to OKT8 (suppressor/ cytotoxic) cells may be increased in rejection ${ }^{6}$ and reduced in clinically apparent cytomegalovirus infection. ${ }^{5}$ Some workers, however, have failed to confirm this finding ${ }^{7}$; the type and degree of immunosuppression may affect the OKT4:OKT8 ratio. ${ }^{8}$ Indeed, the degree of immunosuppression has a direct influence on cytomegalovirus infection-and in particular treatment with antithymocyte globulin increases the risk of severe cytomegalovirus infection, ${ }^{9}$ possibly by causing $\mathrm{T}$ cell depression. ${ }^{10}$

Which patients, then, are at risk of developing severe cytomegalovirus disease? Firstly, reactivation of virus among patients who were seropositive before receiving their transplants is the more common form of infection and is usually less severe than primary infection. ${ }^{11-14}$ The source of cytomegalovirus in primary infection is probably the donor kidney, since infection is rare in seronegative recipients given grafts from seronegative donors. ${ }^{1114} 15$ Orsi et al isolated cytomegalovirus from donor kidneys ${ }^{16}$ and Wertheim et al showed by DNA restriction enzyme analysis that two recipients of kidneys from the same donor excreted cytomegalovirus strains with identical DNA profiles. ${ }^{17}$ Kidneys obtained from cadavers and parents carry a greater risk of infection among recipients than those obtained from child or sibling donors ${ }^{14}$ probably because the incidence of cytomegalovirus infection increases with age.

The risk of cytomegalovirus infection may, therefore, be lessened by careful matching of donor and recipients with respect to cytomegalovirus state. With the shortage of donor kidneys in Britain and with over half of all donors being seropositive this group cannot be excluded; but whenever possible allografts from seropositive donors should not be given to seronegative recipients. ${ }^{13}$ Surprisingly the protocols for neither UK Transplant nor Eurotransplant make any reference to cytomegalovirus state. All renal units have access to virology services for testing markers of hepatitis B virus infection, however, so they should be able also to determine the cytomegalovirus state of donors and recipients.

Another approach to preventing cytomegalovirus infection is to use relatively low dose steroid regimens. ${ }^{18} \mathrm{McGeown}$ et al noted that though infections caused $37.5 \%$ of deaths after renal transplantation reported to the European Dialysis and Transplant Association none of their 100 patients died of infection. ${ }^{19}$ One of the reasons suggested for this disparity was the sparing use of steroids. Whether or not the use of cyclosporin will reduce the incidence of cytomegalovirus infection is not clear. Since cyclosporin acts primarily on $\mathrm{T}$ cell functions one might expect that cytomegalovirus infection would occur more frequently and perhaps be more severe. ${ }^{20}$ So far, however, the findings have been variable. Dummer et $a l^{21}$ and the European Multicentre Trial Group ${ }^{22}$ found no difference in the incidence of cytomegalovirus infection between patients treated with cyclosporin and azathioprine. Petersen et al reported that patients given cyclosporin had responded beneficially-but they used antilymphocyte globulin in the control group. ${ }^{23}$

High titre globulin has been used for the prophylaxis and treatment of cytomegalovirus infection; three reports all found a beneficial effect. ${ }^{24-26}$ Meyers et al found that bone marrow recipients who had received prophylactic globulin had significantly fewer infections than controls, provided that the granulocyte transfusion donors were seronegative for cytomegalovirus. ${ }^{25}$ Winston et al showed that: though giving cytomegalovirus immune plasma resulted in a similar incidence of cytomegalovirus infection in the treated and control groups of bone marrow recipients, the infection was less severe in the treated group. ${ }^{24}$ Recipients of bone marrow transplants are more profoundly immunosuppressed than renal transplant recipients, in whom comparable results might be expected: Condie et al treated 52 such patients with high titre globulin in an uncontrolled trial and concluded that some benefit had occurred. ${ }^{26}$ 
A further method of prevention is the use of cytomegalovirus vaccine. A trial in 1979 showed that all 12 seronegative patients seroconverted, but six excreted cytomegalovirus in their urine after transplantation. ${ }^{27}$ Restriction enzyme studies conducted on strains isolated from four of the patients showed that the DNA pattern was different from that of the vaccine, which had not therefore prevented the patients from becoming infected with different strains of cytomegalovirus. Studies in Minneapolis compared live attenuated vaccine with placebo. ${ }^{28}$ Ninety out of 119 previously seronegative recipients seroconverted. Forty one patients were given transplants, and 17 developed cytomegalovirus infection, seven in the vaccinated group and 10 in the placebo group. Preliminary evidence, however, suggested that the cytomegalovirus infection was less severe among the vaccinees. Similar results have been reported by Plotkin and colleagues. ${ }^{29}$ Perhaps the development of subunit vaccines or vaccine prepared by DNA recombinant techniques will remove the hazards associated with the potential oncogenicity of cytomegalovirus vaccine. ${ }^{30}$ To be effective, however, a cytomegalovirus vaccine must induce an immune response, both humoral and cellular, which persists over the period (unfortunately, often long) that patients remain on a transplant waiting list.

The prophylactic use of acyclovir may provide a further approach to the prevention of cytomegalovirus infection. Gluckman and colleagues recently reported a double blind trial of acyclovir in 39 bone marrow transplant recipients. ${ }^{31}$ In the group treated with acyclovir none developed cytomegalovirus infection while having treatment but four did so later when the drug was stopped. In the placebo group 12 developed cytomegalovirus infection during the study. Recently encouraging results have also been achieved with $\alpha$ interferon. ${ }^{32}$

Treatment of established infection is unsatisfactory, though in a small trial Balfour et al showed that patients treated with acyclovir had low viraemia and improved clinically more rapidly than those given placebo. ${ }^{33}$ Perhaps a higher dosage or the use of a derivation of acyclovir such as DHPG (G-(1,3dexhydroxy-2-propoxymethyl)-guanine; Wellcome 759) may provide more impressive results. Laboratory studies have shown that cytomegalovirus is considerably more sensitive to DHPG than acyclovir; it is also likely to be more toxic.

Several potentially useful methods are, then, available for preventing and treating cytomegalovirus infection in patients with renal transplants, though the studies published have usually been on relatively few patients. Within the not too distant future the optimum method of management may be clearly established, perhaps using a combination of some of these regimens.

T O NUNAN

Senior medical registrar

J E Banatvala

Professor of virology

St Thomas's Hospital,

\section{London SE1 7EH}

Requests for reprints to: Professor J E Banatvala.

${ }^{1}$ Ho M. Virus infections after transplantation in man. Brief review. Arch Virol 1977;55:1-24.

${ }^{2}$ Rifkind D, Goodman N, Hill RB Jr. The clinical significance of cytomegalovirus infection in renal transplant recipients. Ann Intern Med 1967;66:1116-28.

${ }^{3}$ Rubin RH, Cosimi AB, Tolkoff-Rubin NE, Russell PS, Hirsch MS. Infectious disease syndromes attributable to cytomegalovirus and their significance among renal transplant recipients. Transplantation 1977; $24: 458-64$
${ }^{4}$ Richardson WP, Colvin RB, Cheeseman SH, et al. Glomerulopathy associated with cytomegalovirus viremia in renal allografts. $N$ Engl $\mathcal{F}$ Med $1981 ; 305: 57-63$.

${ }^{5}$ Schooley RT, Hirsch MS, Colvin RB, et al. Association of herpesvirus infections with T-lymphocyte-subset alterations, glomerulopathy, and opportunistic infections after renal transplantation. $N$ Engl $\mathcal{f}$ Med $1983 ; 308: 307-13$.

${ }^{6}$ Cosimi AB, Colvin RB, Burton RC, et al. Use of monoclonal antibodies to $\mathrm{T}$-cell subsets for immunologic monitoring and treatment in recipients of renal allografts. $N$ Engl f Med $1981 ; 305: 308-14$.

7 Van Es Ad, van Gemert GW, Baldwin WM, et al. Viral infection and T-lymphocyte subpopulations in renal-transplant recipients. $N$ Engl $\mathcal{f}$ Med 1983;309:110-1.

${ }^{8}$ Morris PJ, Carter NP, Cullen PR, Thompson JF, Wood RFM. Role of T-cell-subset monitoring in renal-allograft recipients. $N$ Engl $f$ Med $1982 ; 306$ :1110-1.

9 Pass RF, Reynolds DW, Whelchel JD, Diethelm AG, Alford CA. Impaired lymphocyte transformation response to cytomegalovirus and phytohemagglutinin in recipients of renal transplants: association with antithymocyte globulin. F Infect Dis $1981 ; 143: 259-65$

${ }^{10}$ Betts RF. Cytomegalovirus infection in transplant recipients. Prog Med Virol 1982;28:44-64.

${ }^{11}$ Ho M, Suwansirikul S, Dowling JN, Youngblood LA, Armstrong JA. The transplanted kidney as a source of cytomegalovirus infection. $N$ Engl f Med 1975;293:1109-12.

12 May AG, Betts RF, Freeman RB, Andrus CH. An analysis of cytomegalovirus infection and HLA antigen matching on the outcome of renal transplantation. Ann Surg 1978;187:110-7.

${ }^{13}$ Betts RF, Freeman RB, Douglas RG, Talley TE. Clinical manifestations of renal allograft derived primary cytomegalovirus infection. $A m \mathcal{F} D i$ is Child 1977;131:759-63.

${ }_{14}$ Peterson PK, Balfour HH Jr, Marker SC, Fryd DS, Howard RJ, Simmons RL. Cytomegalovirus disease in renal allograft recipients: a prospective study of the clinical features, risk factors and impact on renal transplantation. Medicine (Baltimore) 1980 ;59:283-300.

${ }^{15}$ Betts RF, Freeman RB, Douglas RG Jr, Talley TE, Rundell B. Transmission of cytomegalovirus infection with renal allograft. Kidney Int 1975;8:385-94.

${ }^{16}$ Orsi EV, Howard JL, Baturay N, Ende N, Ribot S, Eslami H. High incidence of virus isolation from donor and recipient tissues associated with renal transplantation. Nature $1978 ; 272: 372-3$.

${ }^{17}$ Wertheim P, Buurman C, Geelen J, van der Noordaa J. Transmission of cytomegalovirus by renal allograft demonstrated by restriction enzyme analysis. Lancet $1983 ; \mathrm{i}: 980-1$.

${ }^{18}$ Morris PJ, Chan L, French ME, Ting A. Low dose oral prednisolone in renal transplantation. Lancet 1982 ; i :525-7.

${ }^{19}$ McGeown MG, Kennedy JA, Loughridge WGG, et al. One hundred transplants in the Belfast City Hospital. Lancet 1977; ii :648-51.

${ }^{20}$ White DJ. Cyclosporin A. Clinical pharmacology and therapeutic potential. Drugs $1982 ; 24: 322-34$

${ }^{21}$ Dummer JS, Hardy A, Poorsattar A, Ho M. Early infections in kidney, heart, and liver transplant recipients on cyclosporine. Transplantation $1983 ; 36: 259-67$.

${ }^{22}$ European Multicentre Trial Group. Cyclosporin in cadaveric renal transplantation: one-year follow-up of a multicentre trial. Lancet 1983; ii: $986-9$.

${ }^{23}$ Petersen PK, Rynasiewicz JJ, Simmons RL, Ferguson RM. Decreased incidence of overt cytomegalovirus disease in renal allograft recipients receiving cyclosporin-A. Transplant Proc 1983;15:457-9.

24 Winston DJ, Pollard RB, Ho WG, et al. Cytomegalovirus immune plasma in bone marrow transplant recipients. Ann Intern Med 1982;97:11-8.

${ }^{25}$ Meyers JD, Leszczynski J, Zaia JA, et al. Prevention of cytomegalovirus infection by cytomegalovirus immune globulin after marrow transplantation. Ann Intern Med 1983;98:442-6.

${ }^{28}$ Condie RM, Hall BL, Howard RJ, Fryd D, Simmons RL, Najarian JS. Treatment of life-threatening infections in renal transplant recipients with high-dose intravenous human IgG. Transplant Proc 1979;11:66-8.

27 Glazer JP, Friedman HM, Grossman RA, et al. Live cytomegalovirus vaccination of renal transplant candidates. A preliminary trial. Ann Intern Med 1979;91:676-83.

${ }^{28}$ Marker SC, Simmons RL, Balfour HH Jr. Cytomegalovirus vaccine in renal allograft recipients. Transplant Proc 1981;13:117-9.

29 Plotkin SA, Smiley ML, Freidman HM. Towne-vaccine-induced prevention of cytomegalovirus disease after renal transplantation. Lancet $1984 ; \mathrm{i}: 528-30$.

${ }^{30}$ Balfour HH. Cytomegalovirus disease: can it be prevented ? Ann Intern Med 1983;98:544-6.

${ }^{31}$ Gluckman E, Lotsberg J, Devergie A, et al. Prophylaxis of herpes infections after bone-marrow transplantation by oral acyclovir. Lancet 1983;ii:706-8.

${ }^{32}$ Hirsch MS, Schooley RT, Cosimi AB, et al. Effects of interferon-alpha on cytomegalovirus reactivation syndromes in renal-transplant recipients. $N$ Engl F Med 1983;308:1489-93.

${ }^{33}$ Balfour HH Jr, Bean B, Mitchell CD, Sachs GW, Boen JR, Edelman CK. Acyclovir in immunocompromised patients with cytomegalovirus disease. A controlled trial at one institution. Am f Med 1982;73 (acyclovir symposium):241-8. 